\title{
AZ ANGOL TANÁRKÉPZÉSI RENDSZER
}

\section{KIRÁLY ZSOLT}

az Eötvös Loránd Tudományegyetem Bölcsészettudományi Kar Angol-Amerikai Intézet Angol Nyelvpedagógia Tanszékének habilitált egyetemi docense kiraly.zsolt.dr@gmail.com

A tanulmány az angol tanárképzési rendszert mutatja be, amely számos vonatkozásban eltér a világ legsikeresebb oktatási rendszereiben alkalmazott képzési alapmodellektöl, söt általában véve is éles ellentétben áll a nemzetközi trendekkel, elsösorban az iskolai alapú pedagógusképzés nagyon magas és egyre növekvö részaránya tekintetében. A modell bemutatásán kívül az irás áttekinti a mai helyzet kialakulását, és röviden összefoglalja a rendszerrel kapcsolatos szakmai kritikákat is.

\section{Bevezetés}

Egy-egy ország pedagógusképzésének leírása még egy viszonylag kicsi és erősen központosított országról készült egyszerü pillanatfelvétel esetében is meglehetősen nehéz feladat, ha másért nem, akkor azért, amit Halász Gábor úgy fogalmaz meg, hogy „a pedagógusképzés (...) az oktatás világának talán legbonyolultabb, legszövevényesebb és legtöbb kiszámíthatatlan eseményt ígérő területe, (...) szinte reménytelenül komplex világ" (Halász, 2010. 134. o.). Különösen nehéz összképet adni egy olyan országról, amelynek államszervezete még áttekinthetetlenebbé teszi a rendszert. Ez a helyzet például az olyan szövetségi alapon müködő országok pedagógusképzése esetében, amelyekben a különböző tartományok vagy államok oktatásügyi autonómiát élveznek, és ezért nem is létezik az ország egészére általánosan érvényes szabályozás. Az Egyesült Királyság, pontosabban a jelen tanulmány tárgyát képező Anglia (és Wales) vizsgálata során is ilyen nehézségekbe ütköznénk, itt azonban nem abban az úgymond horizontális értelemben, mint például az USA esetében, hanem inkább vertikálisan, egyszerüen azért, mert részben a történelmi-hagyománybeli okok, másrészt pedig a közelmúlt oktatáspolitikai prioritásai miatt Angliában rendkívül sok különböző módja van a tanárképzésbe való belépésnek. Az angol tanárképzési rendszer másik sajátossága, hogy az alkalmazott modellek tekintetében a világ oktatásügyekben legsikeresebb országainak gyakorlatával sok szempontból homlokegyenest ellenkező stratégiát követ.

A tanárképzést - bár ideális esetben egy kontinuumként kellene értelmeznünk - gyakorlati szempontból három egymásra épülő, de mégiscsak különálló szakaszra szokás osztani. Ennek első fázisa a tradicionális egyetemi/föiskolai tanulmányokra vagy az iskolai betanításra (illetve ezek kombinációira) épülő tanárképzés, amelyet az iskolai indukció, a pedagóguspályára történő munkahelyi belépést közvetlenül követő bevezető-betanuló szakasz követ. A harmadik fázis az élethosszig tartó 
tanulás elvén alapuló, a már pályán lévő tanárokat érintő tanár-továbbképzési szakasz. A következőkben a fenti logikát fogjuk követni az angol tanárképzési rendszer bemutatása során, de előtte még - bár ez szigorú értelemben nem tárgya a jelen vizsgálatnak - nagy vonalakban feltétlenül át kell tekintenünk az angol pedagógusképzés történetét, mert a mai helyzet csak a folyamatos változások és reformok tükrében értelmezhető kellő mélységben. Hasonlóan elkerülhetetlen az angol közoktatási rendszer vázlatos bemutatása is, mivel ennek sajátosságai közvetlen befolyással voltak és vannak a tanárképzés rendszerének alakulására.

\section{A jelenlegi rendszer kialakulása és föbb vonásai}

\section{Rövid történeti áttekintés}

Az angol tanárképzés mintegy két évszázados története során a társadalmi viszonyok és ezzel összefüggésben a pedagógia szemlélet változásai nyomán a legvitatottabb kérdések a következők voltak: a képzés módja, természete és annak legmegfelelőbbnek tartott helyszíne; ebből következően és ezzel párhuzamosan a hatékony tanári munkához elengedhetetlenül szükséges alapvető készségek, szaktudás és hozzáállás definiálása; ezeknek a képzés tartalmában kialakítandó ideális aránya,; a képzés különböző résztvevőinek szerepkörei; valamint az elméleti és a gyakorlati képzés közötti egészséges arányok kialakítása.. A legtöbb polémia Angliában mindig is a képzési alapmodell, azaz az oktatás helyszínén történő, iskolai alapú, betanító jellegü képzés és a főiskolai-egyetemi alapú képzés aktuális dominanciájának kérdéséről folyt. A tanárképzés történetével foglalkozó források az ezzel kapcsolatos - kronológiailag jól követhető - változásokat előszeretettel szokták az inga-metaforával leírni, amelyben az inga az alapvetően iskolai alapú tanárképzési modell - amelynek során a képzés magában az iskolában történik kiképzett, tapasztalt tanárképzö szakemberek felügyelete alatt -, valamint a ma hagyományosabbnak tekintett, döntően felsőoktatási szervezésű tanárképzési forma között mozog. A két modell közötti ingadozás nagy vonalakban úgy vázolható fel, hogy a XIX. században jellemző, alapvetően iskolai alapú képzés dominanciáját (sőt sokáig kizárólagosságát) a XX. század legnagyobb részében felváltotta a szinte teljesen a felsőoktatási intézményekre korlátozódó képzés, míg végül az utóbbi mintegy harmincöt évben ismét határozottan elötérbe került az (egyetemekkel együttmüködésben megvalósított) iskolai alapú képzés. Az egyetemi/főiskolai tanárképzés hegemóniája a kilencvenes évek elején kezdett meginogni, mégpedig azért, mert a kormány (egyéb intézkedésekkel együtt, mint pl. ösztöndijjak, a tanári fizetési skála módosítása stb.) más utakat kezdett keresni az egyre súlyosbodó tanárhiány enyhítésére, a tanári pályát elhagyók pótlására, illetve a tanári pályára való átképzés inspirálására és általában a tanári pályára való bejutás elősegítésére. A konkrét elképzelések először a 2010-es „A tanítás fontossága” címet viselő Fehér Könyvben (Gov.UK, 2010) majd a 2011-es „A kiváló tanárok új generációjának 
képzése" címü konzultációs dokumentumban (Crown copyright, 2011), valamint az ezeken alapuló végrehajtási tervben kerültek nyilvánosságra. Ezek főbb tartalmi elemei úgy foglalhatók össze, hogy emelni kell az iskolai alapú képzés arányát, ehhez új képzési helyeket, ún. Tanító iskolákat (Teaching Schools) kell létrehozni, szigorítani kell a hallgatók felvételéhez előírt alkalmassági tesztet, módosítani kell a finanszírozási és ösztöndíjrendszert, annak érdekében, hogy a hiányszakokra több tanárjelöltet lehessen toborozni, valamint új utakat kell bevezetni a tanári pályára való belépés megkönnyítésére. (Universities UK, 2014. 8. o.)

\section{A jelenlegi rendszer föbb vonásai}

Ma - 2018 áprilisától - az Oktatási Minisztérium és Oktatásigazgatási Hivatal (Department for Education and Teaching Regulation Agency) elnevezésü kormányhivatal feladata az iskolák és a felsőoktatási intézmények közötti partneri viszony szabályozása és felügyelete. A Hivatal felelős a fenti a célok megvalósításáért, ők szabják meg a képzőhelyek által felvehető hallgatók keretszámait, és szinte évente új, iskolai alapú tanárképzési programokat hirdetnek meg. A változások dinamikája rendkívül erős: 2012-13 és 2015-16 között a közvetlenül az egyetemi képzésben részt vevő hallgatók aránya 23\%-kal csökkent (Universities UK, 2014).

Halász Gábor a fentebb már hivatkozott írásában megad egy problémaértelmezési keretet, amely „öt egyszerre vizsgálandó, egymással összefüggő, de mégis külön-külön, ugyanakkor egy időben kezelendő problémadimenziót" határoz meg: a képzési programok szintjei vagy típusai (pl. BA/MA); a képző intézmények eltérö típusai (pl. egyetem/föiskola, maga az iskola); az eltérő szakterületek sajátosságai (pl. humán, természettudományi, müvészeti, technikai, müszaki); a speciális (szakterületekhez kötődő) és az általános (szakterületekhez nem kötődő) kompetenciák; munkaerö-piaci vagy költséghatékonysági szempontok (pl. egyszakos vagy többszakos képzés; első vagy második végzettség) (Halász, 2010. 137. o.) Ez a lista jó kiindulópontnak tünik arra, hogy az itt szereplő szempontok szerint adjunk egy áttekintő képet az Angliában jelenleg érvényben lévő pedagógusképzési rendszerről.

A képzési programok szintjei vagy típusai alapján az angol (állami iskolákra érvényes) rendszer (Initial Teacher Training, ITT) lényegileg egy Bachelor (alap-) szintü, nem osztott rendszerü szaktárgyi képzésre épülő, majd azt egy pedagógiaipszichológiai-módszertani képesítéssel kiegészítő, egy vagy két évig tartó (követő modell), illetve egy ezzel egyenértékü, három-négy éves BA/BEd szintü párhuzamos képzési rendszer, amelyek végén a sikeres pedagógusjelölt az iskolai tanítás megkezdésére jogosító képesítést, ún. Diplomás Tanár Státuszt (Qualified Teacher Status, a továbbiakban QTS), illetve a kiegészítő képzés esetén ún. Posztgraduális Pedagógiai Diploma (Postgradual Certificate in Education, a továbbiakban PGCE) 
elnevezésű, nem mesterszintü végzettséget is $\operatorname{szerez}^{29}$. A tanítás megkezdéséhez elegendő a Diplomás Tanár Státusz megszerzése, amelyet az ún. Tanári Sztenderdeknek (amely egy, a tanárokkal szembeni elvárásokat rögzítő kompetencialista, részletesen lásd később) való megfelelés bizonyítása után kaphat meg a hallgató. Ennél magasabb képesítést (Mester vagy $\mathrm{PhD}$ ) az állami oktatási rendszer elfogad, de nem követel meg, és önmagában semmiféle módon nem is jutalmaz. Az általános vagy középiskolai szintü tanításra való képzésre külön programok vannak, amelyekre igény szerint lehet jelentkezni, de elvileg a tanári diploma birtokában bármilyen szinten taníthat valaki állami fenntartású iskolában, ha egyébként alkalmasságát bizonyítani tudja.

A képző intézmények típusai alapján két alaptípus létezik, a tisztán egyetemek és föiskolák által nyújtott elsődiplomás vagy posztgraduális képzés, valamint az iskola vagy iskolák konzorciuma alapján müködő rendszer, amely az iskolában mentorálással segített oktatómunka mellett, egy-egy egyetemi-föiskolai partnerintézmény közremúködésével juttatja a hallgatót tanári képesítéshez. A két különböző úton elérhető tanári diploma teljesen egyenértékü.

Az eltérö szakterületek sajátosságai (pl. humán, természettudományi, múvészeti, technikai, müszaki) alapján az angol rendszer teljesen szabad, mindenki szabadon választhat bármilyen (lehetőleg, de nem kizárólagosan) olyan tárgyat, amelyet a Nemzeti Tanterv tartalmaz. Mivel bizonyos tárgyak esetében (pl. matematika, fizika, informatika, modern nyelvek) tanárhiány mutatkozik, ezeknél a tárgyaknál külön anyagilag is megtámogatott képzések folynak.

A speciális (szakterületekhez kötődö) és az általános (szakterületekhez nem kötödö) kompetenciák tekintetében az angol rendszer teljes mértékben a Tanári Sztenderdekben lefektetett kompetenciaterületekre és az azokhoz rendelt követelmények legalább minimális (de nem alacsony!) szinten való teljesítésére épül. A Sztenderdek általános pedagógia kompetenciákat és etikai elvárásokat fogalmaznak meg, a szaktárgyakkal kapcsolatos speciális követelmények pedig az egyes ellátók által kínált szakos programok tanterveiben manifesztálódnak.

Munkaerö-piaci vagy költséghatékonysági szempontok alapján - azon kívül, hogy az adott tanárképzési ellátó (egyetem vagy iskolakonzorcium) által felvehető hallgatók számát központilag határozzák meg - az angol tanárképzési rendszerben nincsenek megkötések. Nem szokványos azonban a többszakos (osztott) képzés, és nem létezik a major-minor rendszer sem. Mint láttuk, a tanári képesítés kiegészítő képzés keretében is megszerezhető, és a kötelezően megszerzendő QTS diplomát semmilyen más képesítés nem helyettesítheti.

29 A PGCE az alap és mesterszint között elhelyezkedő, 90 kreditértékű, tehát már mesterszintü krediteket is tartalmazó szint, amelynek megszerzéséhez azonban a hallgatónak nem kell szakdolgozatot benyújtania. 


\section{Az angol iskolarendszer vázlata}

A tanárképzéssel kapcsolatos, a magyar olvasó számára nyilvánvaló (pl. általános és középiskolai tanárképzés eltérő igényeiből következő) összefüggéseken kívül, elsősorban a különböző iskolatípusokra törvényileg elöírt képzési követelmények közötti eltérésekből adódóan, feltétlenül szükséges a meglehetősen összetett angol közoktatási rendszer legalább vázlatos áttekintése.

Első megközelítésben mindössze két, egymástól gyökeresen különböző és tárgyunk szempontjából is nagyon eltérő alaptípus van: egyrészt a helyi Oktatási Hatóságok (LEA) által finanszírozott, a tanulók számára ingyenes állami iskolák (State Schools), másrészt pedig a fizetős magániskolák vagy Független iskolák (Independent-/Private-/vagy Public Schools) kategóriái. Azonban - mindkét kategórián belül - az angol hagyományok és a közelmúltban hozott kormányintézkedések okán is, ma Angliában alig áttekinthetően sok eltérő iskolatípus létezik, amelyek számos szempont (tanterv, tulajdonviszonyok, finanszírozás, a tanárok alkalmazása, felügyelet stb.) tekintetében különbözhetnek egymástól.

A mi vizsgálatunk tárgya szempontjából a legfontosabb a „tanárok alkalmazása" kategórián belül a tanárok alkalmazási feltételei alapján való kategorizálás, amely azt mutatja, hogy fóállásban, tanárként kizárólag a formális, standard tanárképzésben részt vett, azt sikeresen elvégző és az ezzel járó Diplomás Tanár Státuszt elnyert pályakezdőt szabad alkalmazni az olyan állami iskolákban, mint pl. a Közösségi iskolákban (Community Schools) és a legtöbb Akadémián (Academies), míg a nem önkormányzati alapítású Szabad iskolákban (Free Schools), egyes Akadémiákon és a fizetős magániskolákban nincs ilyen követelmény, bár a tapasztalat azt mutatja, hogy a legtöbb ilyen iskolában is elönyben részesítik azokat, akik rendelkeznek ezzel a képesítéssel (University of Oxford, 2018; Brownejacobson, 2012).

\section{Anglia pedagógusképzési rendszerének struktúrája}

Az angol tanárképzési rendszer - eltérően a világban legelterjedtebb modellektöl, beleértve a magyar rendszert is - tehát nem kizárólag az egyetemi-föiskolai tanárképzésre épül, hanem számos egyéb bemeneti lehetőséget kínál a felvételi követelményeknek megfelelő jelentkezők számára.

Amint az 1. ábráról leolvasható, Angliában ma számos (legalább 16 különbözö) módja van a diplomás tanári pályára való bejutásnak. Ennek a sokszínüségnek a fő okai az oktatási kormányzat 1992 után elindított tanárképzési reformjaiban keresendők, amelyek a konzervatív-liberális koalíció kormányzati pozícióba kerülésével, 2010 után kaptak igazán komoly lendületet. A tanárképzés tradicionálisabb formája az alapképzésben elvégzett BEd és BA/BSc típusú szakos alapképzés, illetve a BA/BSc-re épülő másoddiplomás (posztgraduális) képzés útján 
felsőfokú intézményben szerzett tanári diploma, de egyre nagyobb (kb. 50\%) a különböző iskolaalapú, foglalkoztatással egybekötött képzési formák aránya. A tanárképzés ellátói tehát lehetnek maguk az egyetemek/főiskolák, illetve a Tanító iskolák, azaz egyes iskolák vagy azok konzorciuma is, amelyek szabályozott partneri kapcsolatban vannak valamilyen felsőoktatási intézménnyel. Akkreditációra (Tanító iskola státuszra) az iskolák közül csak az Ofsted (a tanfelügyeletért felelős szerv) vizsgálatok során jónak vagy kiválónak minősített iskolák jelentkezhetnek.

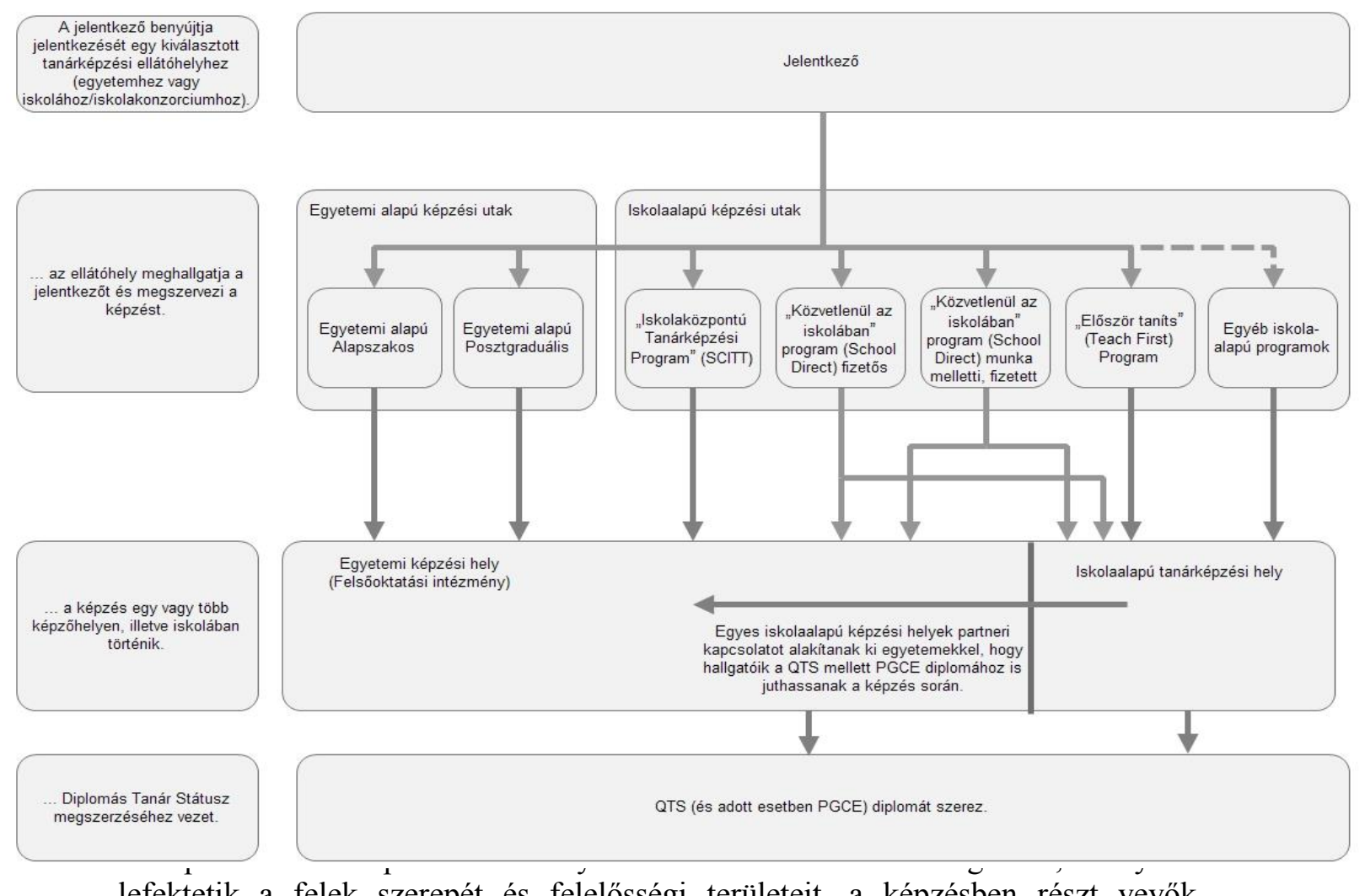

lefektetik a felek szerepét és felelősségi területeit, a képzésben részt vevők felkészítésére és támogatására vonatkozó előírásokat, valamint a pénzügyi források partnerek közötti elosztásának pontos elveit és módját. (Robinson, 2006) A képzés tartalmát és formáját az ellátók maguk dolgozzák ki, majd akkreditáltatják, és ők veszik fel a hallgatókat is (Department for Education, 2018/b; Universities UK, 2014).

Az Oktatási Minisztérium az Oktatásigazgatási Hivatalnak az Ofsted vizsgálatai és egyéb teljesítményindikátorok figyelembevételével készült ajánlásai alapján hozott döntésében minden évben közzéteszi a következő évben szükséges új pedagógusok számát (2015/16-ban ez a szám összesen 33209 volt), és egyben 
meghatározza. hogy az egyes tanárképzési szolgáltatók (ellátók, képzési helyek) milyen számú hallgatót vehetnek fel a képzésükbe.

A tanári pályára való bejutás főbb útjai ma Angliában tehát - valamivel részletesebben - a következők:

- $\quad$ Egyetemi/föiskolai alapú, BA, BSc vagy BEd (alapképzés) szintü képzés keretében, amelyek kombinálják a szaktárgyi és a pedagógiai, pszichológiai és módszertani képzést. Ez az általános iskolai tanárképzés tipikus formája, jelenleg a végzett tanárok 16\% szerezi diplomáját ezen az úton (European Commission/EACEA/Eurydice, 2015).

- Egyetemi/föiskolai alapú, a QTS diplomán kívül PGCE diplomát is adó kurzusok, nem mesterszintű posztgraduális képzés keretében. Ezek a programok elsősorban a pedagógiai, pszichológiai és módszertani képzésre koncentrálnak. Bár Angliában a PGCE nem követelmény a tanári pályára lépéshez, presztízzsel bír, és nemzetközileg is szélesebb körben elismert, mint a pusztán a QTS. A középiskolai tanárok általában ilyen képesítéssel rendelkeznek. A 2015/16-os tanévben a tanárképzésbe felvett hallgatók 41\%-a ebben a képzéstípusban vett részt (Universities UK, 2014).

- Az általában egyéves, ún. „Iskola-központú tanárképzési program” (SchoolCentred Initial Teacher Training, SCITT) keretében. Ez egy már meglévő diplomára épülő, iskolai munkavállalás melletti, a gyakorlati képzést előnyben részesítő képzési forma, amely QTS és legtöbbször PGCE diplomához is vezet. A programot egy iskola vagy még gyakrabban egymáshoz közeli iskolák egy csoportja múködteti, együttmüködésben valamilyen felsőoktatási intézménnyel, de jelentkezni a felsőoktatási intézménybe kell, és ők döntenek a gyakorlati képzés helyszínéről is. A ma felvettek 7\%-a ilyen képzésben vesz részt (Universities UK, 2014).

- A szintén foglalkoztatás melletti, egyéves, „Közvetlenül az iskolában” (School Direct) elnevezésü iskolai alapú képzési program keretében, amely tartalmi és szerkezeti értelemben szinte teljesen megegyezik a SCITT programmal, és amelyet kifejezetten a legalább három éves munkaviszonnyal rendelkező pályamódosítók/átképzősök számára dolgoztak ki. Ez a program is QTS és sok esetben - de nem mindig - PGCE diploma megszerzéséhez vezet. A School Direct programnak van fizetéssel nem járó, valamint nem-diplomás tanári státuszban történő, fizetett iskolai munkavállalás melletti változata is - ez utóbbi változat ma sokkal népszerübb. Ma a tanárképzésben részt vevő hallgatók 10\%-a a fizetéssel nem járó, 21\%-a a fizetett School Direct programban tanul (Universities UK, 2014). Szemben a SCITT programokkal, a hallgatókat itt maga a képző iskola veszi fel, így garantált a képzés helye. Ennek egy újabb változata egy iskolai vizsgával végződő ingyenes „Posztgraduális pedagógus gyakornoki program" (Postgraduate Teaching Apprenticeship), amelyben a fizetett 
tanítási idő minimum $20 \%$-a nem tanítással, hanem valamilyen más (egyetemi vagy iskolai) képzési tevékenységgel telik.

- Az „Először taníts!” (Teach First), vezetői készségekre is koncentráló, kétéves, alapvetően iskolai, de praktikusan kombinált, iskolai- és egyetemialapú program keretében. Ez a program a kiemelkedö alapszakos eredménnyel (2:1 vagy annál jobb) jelentkező hallgatók részére áll rendelkezésre, és az QTS-en kívül vezetői képességeket igazoló PGDE diplomát is ad, valamint 120 kredites mesterképzési részt is tartalmaz, amely lehetőséget nyújt a tanárképzés befejeztével a mesterfokú diploma megszerzésére is. (2002-ben vezették be, ma a hallgatók 5\%-a tanul ebben a képzési típusban.)

A fenti alapvető és leggyakrabban előforduló utakon kívül még számos egyéb speciális mód is létezik a pedagóguspályára való bejutásra, egyrészt olyan szaktárgyak esetében, amelyek Angliában hiányszakoknak minősülnek, másrész pedig olyan szakemberek részére, akik valamilyen speciális háttérrel vagy szakképzettséggel rendelkeznek, és érdeklődnek a tanári pálya iránt. Ilyenek például a „Kutatók az iskolában” elnevezésủ program (Researchers in Schools, RIS), a „Csak értékelés” (Assessment Only) program, a „Fegyveres erőktől az oktatásba” (Troops to Teachers) program, a „Jövő tanító tudósai” (Future Teaching Scholars) program és a „Akkor most taníts!” (Now Teach) program. Ezen programok mindegyike a QTS diploma mellett nem mesterszintű PGCE és (választhatóan) akár mesterszintü diplomához is vezethet (Department for Education, 2018/b; Graduate Prospects Ltd. GB, 2018; UCAS, 2018/a). A felsoroltakon kívül még számos egyéb - még a fentieknél is speciálisabb képzési forma is létezik, amelyeket itt - terjedelmi okokból - még csak meg sem tudunk említeni.

A képesített tanárokon és a tanárképzésben éppen részt vevő tanárjelölteken kívül az iskolák nagy (és egyre növekvő) számban alkalmaznak pedagógiai asszisztenseket (Teaching Assistants), akiknek a dolga a tanárok és általában az iskola munkájának segítése, de sokszor bevonják őket a tanításba is, különösen helyettesítési célból. A pedagógiai asszisztensek - amennyiben megfelelnek az alapvető feltételeknek - elvileg bekapcsolódhatnának a tanárképzésbe, de a gyakorlat azt mutatja, hogy csak mintegy harmaduk szeretne tanári képesítéshez jutni.

\section{A pedagóguspályára való bekerülés feltételei}

A tanárképzési programokba való bekerülés felvételi követelményeit az Oktatási Minisztérium és az annak végrehajtó szerveként müködő Oktatásigazgatási Hivatal (Department for Education and Teaching Regulation Agency) által kiadott törvényerejü rendelet és útmutató kiadvány (Gov.UK, 2018/b) szabályozza.

$\mathrm{Az}$ alapképzési tanárképző programokra (BEd, BA, BSc + QTS) való felvételhez elvárás, hogy a jelentkező a középszintü érettségin (GCSE) minimum 
grade C (a 2017-től érvényben lévő új, számalapú skálán grade 4) minősítést érjen el angolból és matematikából, illetve ezen kívül még egy ugyanilyen eredménnyel kell rendelkeznie egy természettudományi tárgyból is, amennyiben 3 és 11 év közötti gyerekekkel kíván foglalkozni későbbi pályája során (Express, 2017). Ez a „standard pass” szint, amely a kilencfokozatú értékelési skála közepe táján helyezkedik el. 2013 óta minden jelentkező számára kötelező továbbá egy alapvető számtani és angol nyelvi ismereteket vizsgáló teszt sikeres letétele is. A jelentkezőnek ezen kívül rendelkeznie kell a magyar erkölcsi bizonyítványnak megfelelő DBS (Disclosure and Barring Service) okmánnyal, valamint kérhetik, hogy a jelölt orvosi igazolást is mellékeljen a jelentkezési laphoz. A legtöbb felsőoktatási intézménynél (különösen azokon a szakokon, ahol nagy a túljelentkezés) elvárás vagy legalábbis előnyt jelent az, ha a jelentkezőnek van előzetes önkéntes iskolai gyakorlata (óralátogatások és egyéb önkéntes tevékenységek).

A posztgraduális egyetemi képzésekre (PGCE) jelentkező pályázónak rendelkezni kell egy minimum 2:2 minősítésü (a súlyozott tanulmányi átlag alapján kialakított ötfokozatú eredményskála középső minősítése [100-ból 50 és 59 pont között] - second-class honours, lower division) föiskolai/egyetemi alapképzési (BA/BSc) diplomával (bármilyen diszciplínában) (Quora, 2018; University of Liverpool, 2018). Külön lehet jelentkezni általános és/vagy középiskolai tanárképzésre. Amennyiben a jelentkező olyan tárgyból rendelkezik előzetes képzettséggel, amely nem szerepel a Nemzeti Alaptantervben vagy nem azonos a később tanítani óhajtott tárggyal, akkor kötelezhetik egy 12-28 hetes szakképző kurzus (Knowledge enhancement, SKE) elvégzésére is (UCAS, 2018/a).

Az elöírt dokumentumok beküldése után a jelentkezőt behívják egy felvételi beszélgetésre. Ennek tartalmát, hosszát és értékelési módját az adott intézmény (egyetem vagy iskola) szabja meg, és erről tájékoztatják a jelentkezőt. Az interjú egy órától akár egy teljes napot igénybe vehet, és a következő dolgok bármelyikét (akár mindegyikét) tartalmazhatja: beadott dokumentumok áttekintése és megbeszélése, egy csoportfeladat vagy vita (pl. aktuális oktatási kérdésekröl), egy rövid prezentáció egy előzetesen megadott témáról, egyéni elbeszélgetés, amely egy oktatóval vagy bizottság elött zajlik, egy írásbeli feladat vagy feladatok, amelyek lehetnek nyelvi és/vagy szaktárgyi ismereteket vizsgáló tesztek is (UCAS, 2018/a).

\section{A pedagógusképzés tartalmi jellemzői}

A pedagógusképzést tartalmi elemeit általában három területre szokás osztani: a tanítani kívánt szaktárgyra vonatkozó akadémiai tudásra, a tanítás elméletével kapcsolatos ismeretekre (pedagógia, pszichológia, módszertan stb.), valamint a való életbeli tapasztalatokat nyújtó, felügyelet alatt folyó tanítási gyakorlatra, beleértve az óralátogatásokat is. Szemben számos ország gyakorlatával, Angliában a fenti összetevők arányát nem szabályozzák központilag, mindössze a kimeneteli 
követelményeket szabják meg nagyon alaposan - a Tanári Sztenderdeknek való, a végzős hallgatókra előírt szintű megfelelés megkövetelésével. A képző intézmények teljes autonómiát élveznek programjaik összeállításában, a diplomához vezető út tekintetében kizárólag a tanítási gyakorlattal és a korcsoportokra való felkészítéssel kapcsolatosan vannak követelmények lefektetve a központi szabályozásban. Ezen kívül azonban a képzési programoknak akkreditáción is át kell esniük, és az erre kijelölt szerv dönt arról, hogy a képzési terv legalább elméletileg alkalmas-e a hallgatók sikeres felkészítésére. A program beindulása után is folyamatosan ellenőrzik, és ha kell, módosítják a program tartalmát, adott esetben beleértve akár a képzési tartalomelemek arányát is.

\section{A különbözö képzések tantárgyi struktúrája, tantervek}

\section{A tanárképzés szaktárgyi tartalma}

A tanárképzés szaktárgyi tartalmát illetően az általános iskolai tanári képzésben a Nemzeti Tantervben szereplö tantárgyak bármelyike válaszható, ezek konkrét szakmai tartalma azonban intézményenként eltérő. Ezek az ún. KS1 és KS2 tárgyak a következők: angol, matematika, természettudomány, müvészet (art \& design), számítógépes ismeretek, tervezés és technológia (design \& technology), földrajz, történelem, idegen nyelvek, zene, testnevelés, és Wales-ben a walesi nyelv.

A speciálisan középiskolai (ún. KS3) és a középszintü érettségire (GCSE) felkészítő (KS4) tárgyak a következők: matematika, angol, állampolgári ismeretek, számítástechnika, testnevelés, müvészet (arts), tervezés és technológia (design \& technology), társadalomtudomány és modern idegen nyelvek. Ezeken kívül tanulható még dráma, tánc, médiaismeretek, hittan, pályaorientáció, valamint szexuális felvilágosítás.

\section{A tanárképzés nem szaktárgyi tartalma}

A tanárképzés nem szaktárgyi tartalmának főbb területeit általánosságban a tágabb értelemben vett pedagógiai és pszichológiai ismeretekben, az oktatás- és szakmódszertanban (beleértve a technológiai ismereteket, az értékelés és a kurzustervezés kérdéseit stb.) és a tanítási gyakorlatban szokás megjelölni. Az angol tanárképzési rendszer alapdokumentumának számító törvényerejü rendelet és útmutató (Gov.UK, 2018), azonban ezek közül a területeket közül csak két elemet szabályoz részletekbe menően: a gyakorló tanítást, és a blokkosított korosztályi képzésre vonatkozó előírásokat. A képzés ezen aspektusai az akkreditált program szerves részét képezik. 


\section{Gyakorló tanítás}

A gyakorló tanítás tekintetében a következő kötelező elóírások vannak érvényben:

- a négy éves alapszakos (undergraduate) programok esetében a gyakorló tanítással töltött időt 160 napban, azaz 32 hétben szabja meg;

- $\quad$ az egy-, kettö- vagy hároméves alapszakos programoknál az előírt tanítási gyakorlat 120 nap, azaz 24 hét;

- a középiskolai és az általános iskolai specializációs, nem foglalkoztatási alapú kiegészítő (graduate/postgarduate) képzési programok esetében szintén 120 nap, azaz 24 hét;

- a foglalkoztatás alapú programok esetében nincs számszerü megkötés, a dokumentum csak annyit mond, hogy ennek mértékét a képzési terv állapítja meg, de ebben az esetben a tanítási napok száma nyilván jóval meghaladja a fenti számokat. Annyi korlátozás azonban van, hogy az ilyen programokban rész vevők óraszáma nem haladhatja meg a fóállású pedagógusok óraszámának 90\%-át (Gov.UK, 2018).

Előírás, hogy a tanítási gyakorlatot minimum két különböző iskolában kell teljesíteni - amelyek közül az egyik lehet akár speciális iskola is -, hogy a hallgatók tapasztalatokat szerezzenek különböző hátterü tanulók tanításában és szokják az általuk ismerttől eltérő iskolakultúrát, iskolaszervezési és iskolavezetési stílust.

\section{$\underline{\text { Korosztályos képzés }}$}

A képzési tartalmat közvetlenül befolyásoló másik fontos elöírás, hogy minden képzési programnak a következő három, egyenként minimum négy tanítási évet átfogó korosztály tanításának valamelyikét prioritásként kell kezelnie, és ennek megfelelően az adott korcsoport tanításához szükséges tudásanyagot és készségeket figyelembe véve kell a programot összeállítani:

- 3-tól 7 éves korig (ezen belül külön is lehet az óvodai képzés 3-tól 5 éves korig), illetve 5-től 11 éves korig az általános iskolások oktatásáranevelésére (óvodától a 6. osztályig);

- 7-től 14 éves korig a középső korosztály oktatására-nevelésére (3.-tól 9. osztályig; ez már hivatalosan középiskolai szintnek számít);

- $\quad$ 11-től 16 éves korig, illetve 11-től 18 éves korig, vagy 14-től 19 éves korig (7-től 12., illetve 13. osztályig) középiskolai oktatásra-nevelésre, függően a képzés szaktárgyi tartalmától.

A QTS diplomára való megfelelés értékelésénél a Tanári Sztenderdeket mindig az adott korcsoportra vonatkoztatva kell értelmezni, amihez segédanyagok nyújtanak segítséget. 
Egyéb tartalmi elemek

A fentieken kívül a dokumentum a tanárképzés tartalmi kritériumaként csak a kimeneteli követelményeket jelöli meg. Ezek a kimeneteli követelmények a 2012 óta érvényben lévő Tanári Sztenderdekben testesülnek meg, amelyeknek megfelelő szinten való teljesítése a tanári diploma (QTS) megszerzésének egyetlen feltétele.

Tantárgyak vagy tudományterületek említése nélkül a képzés konkrét tartalmi elemeit illetően a dokumentum mindössze annyi iránymutatást ad, hogy a képzés „feltehetően” a következő föbb témákat fogja magába foglalni: a tanár szerepe, tervezés és értékelés a tanulói fejlődés/fejlesztés biztosítására, országos felmérések és vizsgák, gyermekfejlődéstan és tanulás, olyan kiemelt területek, mint a tanulói viselkedés kezelése, az olvasás tanítása és a speciális nevelési igényü tanulókkal kapcsolatos kérdések, a tanítás hatékonyságának mérése és értékelése, valamint adatok és kutatások felhasználása az oktatásban (Gov.UK, 2018).

Ennek megfelelően az egyes képzőhelyeknek teljes autonómiát élveznek a tanárképzés nem gyakorló tanításra vonatkozó tartalmi aspektusai tekintetében. Ahány képzési program, annyi különböző kurzus és egyéb képzési forma létezik, a lényeg az, hogy a program készítse fel a hallgatókat a QTS diploma megszerzésének feltételét jelentő Tanári Sztenderdek teljesítésére.

A különböző képzési programok tartalmi közös nevezőjének tehát annyi tekinthetö, hogy mindegyik program nyújt valamilyen akadémiai képzést a sikeres tanításhoz szükséges tudás megszerzéséhez, valamint minden hallgatónak teljesíteni kell 120 napnyi gyakorlati tanítást legalább két különböző iskolában, amelynek során képzett és tapasztalt mentorok biztosítják a szakszerü segítséget és felügyeletet az osztálytermi menedzsment gyakorlatban történő elsajátításához. Minden hallgatónak jár a tanítási készségek fejlődésének folyamatos értékelése is tanulmányai során.

A tanári végzettséget nyújtó képzésben résztvevő intézményeknek rendelkezniük kell a miniszter engedélyével, programjaikat akkreditáltatni kell az Oktatásigazgatási Hivatallal, amely felügyeli is magukat a programokat, valamint az Ofsted vizsgálja, hogy a QTS odaítélése a szakmai sztenderdeknek megfelelően történik-e (Gov.UK, 2018/a).

\section{$\underline{\text { A Tanári Sztenderdek }}$}

A Tanári Sztenderdeknek kiemelt jelentősége van a tanárképzésben, hiszen áttételesen meghatározzák, vagy legalábbis erősen körvonalazzák a képzési programok tartalmi elemeit. A ma is érvényben lévő 2012-es Tanári Sztenderdekről szóló új rendelet (Crown copyright, 2012) a régi, 2006-os, szintekre bontott, rendkívül aprólékos Nemzeti Sztenderdeket egységesítette és számukat is drasztikusan csökkentette. Az új lista 8 tanításra és 3 tanári etikára vonatkozó alapsztenderdet (és összesen 41 alpontot) tartalmaz (Gov.UK, 2012). 
A mai rendszer egyensúlyra törekszik az általános pedagógiai, a szaktanári és etikai szempontok között, egyszerúen definiált, áttekinthető követelményeket fogalmaz meg, és elvárásai nem csak a végzős hallgatókra, hanem később minden pályaszinten minden tanárra vonatkoznak és a pályaszintnek megfelelően rugalmasan értelmezendőek az értékelés során. A kompetencialista tanári pályaszinteknek megfelelő értelmezését és az annak megfelelő értékelést ('igy a QTS szint értékelését is) az értékelők ,józan belátására” bízzák, de különböző segédanyagokban részletesen értelmezik a sztenderdeket, és indikátorlistákkal segítenek a szintnek megfelelö értékelésben (The Higher Education Academy, 2012; Gov.UK, 2018/b; lásd még részletesebben: Király, 2013/a, Király, 2013/b és Király, 2013/c).

\section{Minőségbiztosítás és értékelés}

Alapesetben a tanárképzés minden aspektusának minőségbiztosítása a képzést nyújtó ellátó kötelessége, ami a képzés minőségének folyamatos belső ellenőrzését, értékelését és moderálását jelenti. Kulcskérdés ezen belül a QTS megítélésének kérdése, azaz annak eldöntése, hogy a hallgató megfelel-e a Tanári Sztenderdekben lefektetett - az adott korcsoportokra vonatkozó, a végzős hallgatókra szabott követelményeknek.

Elvárás, hogy az értékelés pontos, megbízható és időben ne pontszerü, hanem folyamatos legyen. Ehhez az akkreditációs dokumentumban a képzési folyamat különböző fázisaira bontva, pontosan meg kell jelölni az értékelés módszereit és kritériumait. Minden értékelés nagy tapasztalatokkal rendelkező belső (internal moderators) és a programtól független külső értékelők (external moderators) bevonásával történik, akiknek az értékelés során adatokat kell gyüjteni a képzés különböző aspektusairól.

\section{A pedagógusképzés finanszírozási modellje, ösztöndíjak}

\section{A tanárképzés ellátóinak finanszírozása}

A tanárképzés ellátóinak finanszírozás Angliában a tandíjon keresztül történik. A tandíjat először 1998-ban, a munkáspárti kormány alatt vezették be. Ekkor ezt $£ 1000$-ben maximálták, de ez az összeg az évek során fokozatosan emelkedett, majd 2010-ben drasztikusan £9000-ra emelték fel. 2017-18-tól a maximális összeg az infláció mértékében nő, illetve fog nőni évente, így jelenleg (2017-től) évi £9250 az Egyesült Királyság és az EU országok hallgatói számára. A különböző ellátók 76\%a a maximális összeget kéri a hallgatóktól. Pontosan ilyen összegü diákhitel vehető fel a legtöbb egyetemen, de a magánegyetemeken a felvett hitel csak maximum $£ 6000$ lehet (UCAS, 2018/b; UCAS, 2018/c). 
A tanárképzésben részt vevő hallgatók finanszírozása

Angliában számos különböző modell létezik a törvényileg maximált tandíj és a megélhetési költségek finanszírozására, amelyek jellege és összege a képzés típusától, a tanítani kívánt tantárgytól, valamint a hallgató egyéni életkörülményeitől függ.

Adómentes tanulmányi ösztöndíjra elsősorban bizonyos erősen hiányszaknak számító tárgyak (fizika, matematika, kémia, számítástechnika, modern nyelvek és földrajz) esetében lehet pályázni, a rászorultság és a megfelelő tanulmányi eredmények függvényében (scholarships), sőt egyes tantárgyak esetében ez szinte automatikusan jár (bursaries). (2017/18-as tanévben ez az összeg $£ 3000$ és $£ 30000$ között van egy före és egy tanévre számolva.) Az ösztöndíjakat az Oktatásigazgatási Hivataltól maguk a képzést ellátók kapják meg, és az ő feladatuk az összegek továbbítása a hallgatók felé. Az ösztöndíjak megítélésének aktuális feltételeit, metodikáját is a Hivatal teszi közzé minden évben (The National College for Training and Leadership, 2018; Gov.UK, 2018/d).

Ha a hallgató nem foglalkozás melletti képzésben akar részt venni és nem jogosult tanulmányi ösztöndíjra, tandíj- és megélhetési költség-hitelekre pályázhat. Az alapszakos, nappalis hallgatók mindegyike, 2014-től pedig már a posztgraduális képzésben részt vevő hallgatók is igénybe vehetik a tandíjra vonatkozó hitelt. A megélhetési ösztöndíjak a 2016/17-es tanévtől megszüntek, így az azóta belépő új hallgatók számára ez a támogatás már csak hitel formájában hozzáférhetö. Összege - bár egy minimumösszegre minden hallgató jogosult - a hallgató családi hátterétől és attól függ, hogy a hallgató otthon lakik-e vagy sem. A foglalkoztatás melletti, iskolaalapú School Direct és a Teach First programok hallgatói fizetést kapnak a képzés során, és tandíjat sem kell fizetniük.

Az ösztöndíjakat természetesen nem kell visszafizetni, de a hiteleket igen. Azonnal vissza kell fizetni a felvett kölcsönt, amennyiben a hallgató megszakítja tanulmányait. A 2012 szeptembere utáni, ún. 2. konstrukció alatt felvett hitelek visszafizetését (havi összegekben) akkor kell megkezdeni, amikor a munkavállaló éves fizetése meghaladja a £21000-ot. (Ha valamiért menet közben ez alá csökkenne, akkor szünetel a visszafizetés.) A visszafizetés mértéke a fenti összeg feletti fizetés 9\%-a. A kamat mértékének megállapítása az előző évi adóbevallás alapján történik, és a minimumösszeg feletti fizetés mértékétől függ; általában az infláció hivatalos mértéke plusz 3\% (ez ma összesen kb. 6\%) (Gov.UK, 2018/e; Graduate Prospects Ltd. GB, 2018). 


\section{A pályakezdő pedagógusok indukciója}

A gyakornokság intézményét eredetileg az 1998-as Közoktatási és felsőoktatási törvény - (Teaching and Higher Education Act, 1998) írta elö, amely aztán 2003-tól kezdve vált egységes formában az egész országban kötelező gyakorlattá. A gyakornoki időszakra vonatkozó jelenleg érvényben lévő alapdokumentum a 2012ben elfogadott rendelet: The Education (Induction Arrangements for School Teachers) (England) Regulations 2012 No. 1115. (Legislation.gov.uk, 2012; Gov.UK, 2018/c). A rendelet mind a mentorálást, mind pedig az értékelést az iskola feladatává tette. A pályakezdő tanár (Newly Qualified Teacher, NQT) az erre a pályaszakaszra vonatkozó fizetési kategóriába kerül. A gyakornoki időszak teljesítése kötelező minden államilag fenntartott iskolában tanító tanár számára, de nem kötelező a magániskolákban és az emelt szintü érettségire (A-level exams) felkészítö ún. Six-form college-okban, a szakképző intézményekben (Further Education Colleges - FEs) tanítók számára. A gyakornoki időszak teljesítésének nincs elöírt határideje, a QTS megszerzés után bármikor megkezdhető, viszont sikertelenség után nem ismételhető.

Az indukció célját úgy fogalmazzák meg, hogy az hidat képez a tanárképzés és a pedagógusi pálya között és megalapozza a tanár hosszú távú továbbképzését. Egy olyan programként írják le, amely egyszerre egy mentorálással segített, személyre szabott, fejlesztési, támogatási és szakmai dialógus, valamint egy, a Tanári Sztenderdek alapján végrehajtott értékelési folyamat.

A gyakornoki időszak általában három trimeszter (egy tanév) hosszúságú, amelyet azonban nem feltétlenül kell egyvégtében és ugyanabban az iskolában teljesíteni. A gyakornok számára a rendelet szerint órakedvezmény jár, ami kötelezően 10\%-kal csökkentett óraterhelést jelent, hogy a gyakornok el tudja végezni a számára kijelölt speciális feladatokat. A gyakornok jogosult egy megfelelő képesítéssel, tapasztalattal és elegendő idővel rendelkező mentor támogatására a folyamat teljes időtartama során.

A gyakornok fejlődését a rendszeres informális visszajelzési és értékelési megbeszéléseken tekintik át, amelyekben külön hangsúlyt kapnak a tanár egyéni szükségletei, azaz azok a területek, amelyekben a legjobban teljesít, illetve ahol teljesítményében esetleg hiányosságok mutatkoznak. A végső értékelés alapját a Tanári Sztenderdeknek a pályakezdőtől elvárható szinten való teljesítése képezi, és a záró megbeszélés utáni döntést végső soron mindig az igazgató hozza meg a „bizonyítékok” (az értékelési lapok és az egyéb dokumentumok) alapján. A gyakornoki időszak sikeres teljesítésével a tanár a fizetési főskálára kerül (ez jelentős fizetésemeléssel jár), viszont amennyiben valaki nem tudja teljesíteni a követelményeket, azt örökre kizárhatják a pedagóguspályáról (Király, 2013/c). 


\section{A tanártovábbképzés rendszere}

Bár minden oktatással kapcsolatos dokumentumban kiemelten szerepel, hogy az angol tanárképzési rendszer az élethosszig tartó tanulás elvére és a folyamatos szakmai fejlődés gondolatára épül - azaz egységet alkot a pedagógusok alapképzése, a pályakezdés (az indukciós időszak) és a gyakorló pedagógusok szakmai továbbfejlődésének folyamata -2012 óta ez utóbbira nem létezik központi, törvényi szintű szabályozás. A kormányzat azonban továbbra is biztosítja a szükséges anyagi forrásokat, tehát a továbbképzés a tanár számára ingyenes maradt: a folyamatos szakmai fejlődés finanszírozására Angliában minimum évi 200 millió fontot költenek, de egyesek szerint könnyen lehet, hogy ennek a többszöröséről van szó (Weston, 2012). A továbbképzés szervezetileg szinte teljesen decentralizált, a finanszírozás alapesetben közvetlenül az iskolákon keresztül történik, pántlikázás nélkül, így az iskolák és az érintett a tanárok az iskolavezetés által a költségvetés erre a célra elkülönített összegének keretein belül maguk döntenek továbbképzési igényeikről az Iskolai Pedagógiai Programban lefektetett követelményeknek és céloknak megfelelően. A döntésekben figyelembe veszik a kormányzat speciális támogatásokkal kapcsolatos aktuális döntéseit, valamint figyelnek arra, hogy a tantestületen belül igazságos legyen a források elosztása, és hogy a pénzt minél ésszerübben és hatékonyabban költsék el. Az ezzel kapcsolatos munkát egy, az igazgató által kijelölt iskolai koordinátor irányítja.

Ennek köszönhetően egyre elterjedtebbek az olyan, iskolára szabott képzési formák, amelyeket a kereslet hív életre. Egyre jellemzőbb, hogy a képzéseket - a speciális igényeknek megfelelően - maguk az iskolák rendelik meg, valamint megjelentek új, iskolai alapú képzési formák is. Így például az iskolai minőségbiztosításban való részvétel, a tantervkészítés, valamint a pedagógiai kutatás is tanulási folyamatként értelmeződik, amely része lehet a továbbképzésnek. Az egyéni tanulás mellett - amikor például valaki egymaga végez el egy továbbképző kurzust - egyre gyakrabban alkalmaznak olyan továbbképzési formákat is, amelyekben a tanári kar több tagja vagy egésze közösen vesz részt valamilyen tevékenységben. Tartalmilag a továbbképzés is alapvetően a Tanári Sztenderdekre és (részben) központilag kijelölt, kiemelt területekre (prioritásokra) épül - ilyen értelemben tartalmilag egységes, így összefügg a szakfelügyelettel, az értékelési rendszerrel és a pályamodellel, illetve annak egyes állomásaival (Király, 2013/b).

A továbbképzési igények azonosításának leggyakoribb módja az egyes iskolákban müködő teljesítményértékelő rendszer alkalmazása során szerzett információkból való kiindulás - mind az érintett tanár, mind az iskolavezetés számára. A teljesítménymenedzsment célja az, hogy az értékelő és az értékelt meg tudjon egyezni abban, hogy a teljesítmény javításához mire van valakinek szüksége és hogy ez hogyan érhető el. Az értékelési ciklus strukturált rendszert biztosít a továbbképzési igények azonosítására és egyben arra is, hogy nyomon lehessen követni a továbbképzés hatékonyságát. 


\section{A tanári pálya megbecsülése, presztízse, vonzóvá tétele}

A tanári pálya presztízse Angliában az OECD jelentése szerint Európában jónak tekinthetô: az országot azok közé a térségek közé sorolja, ahol a pedagóguspályát alapvetően vonzónak tartják $(O E C D, 2017)$. A pálya vonzerejét sok különböző tényező alapján mérik, de nem kétséges, hogy ezek közül az egyik legfontosabb a fizetések mértéke. Az órabérben számolt fizetés Angliában messze az EU átlaga felett van (például a magyarnak közel hatszorosa) és reálértékben stabilnak mondható, annak ellenére, hogy mind a felsőfokú végzettségüek, mind pedig a hasonló szintű végzettségüek országos átlagánál kevesebbet keresnek a tanárok (azok 90, illetve 80\%-át. (OECD, 2017) 2016-ban a rész- és teljes munkaidőben foglalkoztatott tanárok átlagos fizetése $£ 38400$, az igazgatóság tagjainak pedig $£ 63200$ volt. A tanári fizetések emelkedése hosszabb ideje évente $1 \%$-ban volt maximálva, de a demográfiai változások (több gyerek) miatti és a relatív (bizonyos szakok esetében és regionálisan) tanárhiány miatt 2017-ben ezt a maximumot 2\%-ra emelték (bár az igazgatósági fizetések továbbra is csak 1\%-kal nőttek). A tanári fizetéseket az Oktatási Miniszter által kiadott, évente frissített „Tanári fizetésekről és alkalmazási feltételekről szóló rendelet" sávosan, a tanár fizetési skálán elfoglalt aktuális pozíciója alapján szabályozza. A fizetési sávokon belül az iskola vagy annak fenntartója határozza meg a pontos összeget, a skálaszakaszon belüli előmenetel stádiuma, a feladatok jellege, az iskola földrajzi elhelyezkedése (a legmagasabb fizetések Londonban vannak, elsősorban a magas megélhetési költségek okán) és az iskola mérete függvényében (Király, 2014).

2000 eleje óta számos intézkedés történt a tanári pálya vonzóbbá tétele érdekében, új belépési utakat nyitottak, és (különösen a tandíj bevezetése óta) lényegesen megnőtt az ösztöndíjak száma és a kedvező feltételekkel felvehető diákhitelek szerepe. Az OECD 2017-es jelentése szerint az Angliában dolgozó pedagógusok az európai átlagnál jobbnak tartják a pálya társadalmi megbecsülését, és ezt, valamint a tanulókkal való jó kapcsolatot tartják a leglényegesebb szempontoknak a pálya vonzereje tekintetében (OECD, 2017).

\section{A jelenlegi helyzet és a rendszer kritikája}

2015-re a kormányzati intézkedések hatásai már jól érzékelhetőek voltak: az adatok szerint az iskolai alapú és az egyetemi/föiskolai képzőhelyek aránya megközelítőleg egyenlő volt, és az elóző évekhez képest nött a tanárképzésbe felvett hallgatók összlétszáma is. Ezen belül az előző évekhez képest azonos szinten maradt az egyetemi szervezésü BA (undergraduate) képzésben részt vevők száma, viszont erőteljesen csökkent az egyetemi alapú posztgraduális képzésben részt vevők száma és aránya. Az iskolai alapú képzésben részt vevők legnagyobb része (kb. $44 \%$-a) a School Direct programokon, a többiek pedig a SCITT és egyéb programokon keresztül kerültek be a képzésbe. Erőteljes volt az előző időszakhoz képest a 
hallgatók létszámának csökkenése az egyetemi alapú általános iskolai szintủ képzési programok esetében, míg a középiskolai szintü programoknál nem változott (sőt némileg nőtt) az egyetemi alapú képzési helyek száma. Az előző évekhez képest 2016-ra átrendeződött a különböző tantárgyakra felvettek létszáma is: többé-kevésbé az irányelveknek megfelelően némileg nőtt a matematika, a fizika, a biológia és a hittan tárgyakra felvettek száma, míg csökkent az angol, a kémia, a történelem és a modern nyelveket tanulók száma.

A 90-es évektől, majd a 2000-es évek elejétől, főleg pedig 2011 után, a különböző politikai irányzatú kormányokat átívelően lényegében változatlan kormányzati politika, amely szerint növelni kell az iskolai alapú képzés arányát, elsősorban az egyetemek és főiskolák érdekeivel megy szemben, már csak azért is, mert ez a folyamat a bevételi források (tandij) drasztikus átcsoportosításával jár, így sok felsőoktatási intézményt létében fenyeget. Nem meglepő tehát, hogy a legtöbb kritika a tanárképzés iskolaalapúra történő átalakulását érte, mindenekelőtt (de nem kizárólag) az egyetemek részéről. Számos tanulmány és közlemény jelent meg a helyzet értékelésére, amelyek közül talán a legátfogóbb a Universities UK kiadványa, amelynek címe „Az egyetemek finanszírozási környezete - a tanárképzési reformok hatása az angol felsőoktatási intézményekre" (Universities UK, 2014).

Most, hogy egyre erőteljesebben nő az iskolai képzésen alapuló új programok aránya - csak 2012-13 és 2015-16 között 23\%-kal csökkent a közvetlenül az egyetemekhez allokált képzési helyek száma (ez 2011-ben még 80\% volt!) -, az egyetemeknél tetemes csökkenés következett be a tanárképzésben részt vevők számában, bár az iskolaalapú programokban való partneri szerepvállalás ezt több intézménynél is valamelyest kompenzálja. A változások rendkívül gyors üteme és a felvehető hallgatók számának évenkénti közlése csak fokozza az felsőoktatási intézmények financiális instabilitását, mivel nagyon rövid idő áll rendelkezésre a programok tervezésére.

Ugyanez a kiadvány azt állítja, hogy az OECD szerint az angol tanárképzési gyakorlat - az iskolai alapú képzés felé történő elmozdulás - szembe megy a világ legsikeresebb oktatási rendszereiben alkalmazott gyakorlattal és általában a nemzetközi trendekkel. Ezekben az országokban ugyanis az egyetemek kulcsszerepet játszanak a tanárképzésben (Universities UK, 2014).

Számos sajtóközlemény foglalkozott az angol tanárképzés kérdéseivel az elmúlt években. Ezek a cikkek gyakran a tanárképzést az oktatásügy általános problémáinak egyik okaként jelölik meg. A Conversationist weboldal például arra hívja fel a figyelmet, hogy miközben egyre több nevelési témában várják el a tanároktól, hogy szakértő szinten tudják kezelni a felmerülő problémákat (pl. a tanulók mentális problémáinak felismerése, a speciális nevelési igényủ tanulókkal való bánásmód, a nemi diszkrimináció kezelése, a szexuális abúzus felismerése, a tehetséges gyerekekkel való foglalkozás stb.), maga a tanárképzés egyre inkább a tanításközpontú képzés felé tolódik el, és egyre rövidebbé és csökevényesebb 
pedagógiai tartalmúvá válik a tanárok elméleti felkészítése (The Conversationist, 2016).

A Guardian, amely liberális irányzatú lap, és mint ilyen, ma ellenzéki szócsőnek számít, számos írásában hívja fel a figyelmet az oktatási rendszer és azon belül a tanárképzési rendszer hiányosságaira. Így több cikk is figyelmeztet arra, hogy ma több mint 600 ezer angol diákot képesítés nélküli tanár tanít, illetve arra, hogy az állami oktatásban a pályakezdő tanárok mintegy harmada pályát vált az első öt éven belül, valamint, hogy a tanárok munkaterhelésének beígért csökkentése - bár ez valóban az egyik fö problémát igyekszik kezelni - önmagában nem lesz elég a pályaelhagyás mértékének visszaszorítására. A cikkek egyik fő konklúziója az, hogy a tanároknak időre, autonómiára, kollegiális együttmüködésre, szakmai továbbképzési lehetőségekre van szüksége, valamint föleg arra, hogy pozitív visszajelzést kapjanak arról, hogy a vezetőség nagyra értékeli a jól végzett munkát (The Guardian, 2017/a; The Guardian, 2016; The Guardian, 2017).

$\mathrm{Az}$ általam megkérdezett, a tanárképzésben aktívan részt vevő neves angol szakemberek egybehangzó véleménye szerint az angol tanárképzés leginkább fejlesztésre szoruló területe ma egyértelmüen a mentorálás minőségében mutatkozó hatalmas különbségekkel és - ezzel összefüggésben - a mentorok képzésével (illetve annak hiányával vagy hiányosságaival) kapcsolatos problémakör (Hobson, 2013; Malderez, 2013).

\section{Irodalom}

BBC (2014): Troops-to-teachers scheme attracts 102 recruits http://www.bbc.com/news/education-28263223 Letöltés ideje: 2018. 02.15.

Brownejacobson (2012): Schools and academies are no longer required to employ teachers with QTS https://www.brownejacobson.com/education/training-andresources/legal-updates/2012/09/schools-and-academies-are-no-longerrequired-to-employ-teachers-and-qts Letöltés ideje: 2018. 02.15.

Crown copyright (2011): Training our next generation of outstanding teachers https://www.gov.uk/government/uploads/system/uploads/attachment_data/file/1 75363/DFE-00054-2011.pdf) Letöltés ideje: 2018. 02. 15.

Crown copyright (2012): Induction for newly qualified teachers (England) Statutory guidance for appropriate bodies, head teachers, school staff and governing bodies Revised December 2012 http://www.education.gov.uk/schools/leadership/deployingstaff/newstaff/b0066 959/nqt-induction Letöltés ideje: 2018. 02. 15.

Department for children, schools and families \& Statistical National Statistics (2008): Bulletin The Composition of Schools in England June 2008 http://webarchive.nationalarchives.gov.uk/20130321145625/https://media.educa tion.gov.uk/assets/files/pdf/b022008pdf.pdf Letöltés ideje: 2018. 02. 15.

Department for Education (2017): TALIS 2013 Working Conditions, Teacher Job Satisfaction and Retention Statistical working paper November 2017 Sam Sims, Education

Datalab 
https:/www.gov.uk/government/uploads/system/uploads/attachment_data/file/6 56249/TALIS_2013_Evidence_on_Working_Conditions_Teacher_Job_Satisfac tion_and_Retention_Nov_2017.pdf Letöltés ideje: 2018. 02. 15.

Department for Education (2017/a): School Workforce in England: November 20162017 $\begin{array}{llll}\text { SFR 25/2017, } & 22 & \text { June }\end{array}$ https://www.gov.uk/government/uploads/system/uploads/attachment_data/file/6 20825/SFR25_2017_MainText.pdf Letöltés ideje: 2018. 02. 15.

Department for Education (2017/b): Schools, pupils and their characteristics: January 2017 SFR 28/2017, 29June 2017 https://www.gov.uk/government/uploads/system/uploads/attachment_data/file/6 50547/SFR28_2017_Main_Text.pdf Letöltés ideje: 2018.02. 15.

Department for Education (2018/b): Get Into Teaching https://getintoteaching.education.gov.uk/explore-my-options/teacher-trainingroutes Letöltés ideje: 2018. 02. 15.

Department for Education (2018/c): Induction for newly qualified teachers (England) Statutory guidance for appropriate bodies, headteachers, school staff and governing bodies https://www.gov.uk/government/uploads/system/uploads/attachment_data/file/5 80039/Statutory_Induction_Guidance_December_2016.pdf Letöltés ideje: 2018. 02. 15.

DfE (1992): Initial Teacher Training: Secondary Phase, Circular 9/92. HMSO, London.

DfE (1993): The Initial Training of Primary School Teachers: New Criteria for Courses, Circular 14/93. HMSO, London.

DfE (2012): The Education (Induction Arrangements for School Teachers) (England) Regulations 2012, 2012 No. 1115 EDUCATION, ENGLAND http://www.legislation.gov.uk/uksi/2012/1115/made Letöltés ideje: 2018. 02. 15.

DfEE (1997): Teaching: High Status, High Standards - Requirements for courses of Initial Teacher Training: Circular 10/97, London, Her Majesty's Stationery Office, London

European Commission/EACEA/Eurydice (2015): The European Higher Education Area in 2015. Process Implementation Report. Publications Office of the European Union. Bologna - Luxembourg.

Express (2017): What are the new GCSE grades? 1-9 grading system replaces $A^{*}-G$ https:/www.express.co.uk/news/uk/844937/GCSE-results-day-2017-gradeswhat-are-new-grading-system Letöltés ideje: 2018. 02. 15.

Gov.UK (2010): The Importance of Teaching: The Schools White Paper 2010 https:/www.gov.uk/government/publications/the-importance-of-teaching-theschools-white-paper-2010 Letöltés ideje: 2018. 02. 15.

Gov.UK (2012): Teachers' Standards, DfE, May 2012 https://www.gov.uk/government/publications/teachers-standards Letöltés ideje: 2018. 02. 15.

Gov.UK Department for Education \& The National College for Teaching and Leadership (2018): Initial teacher training (ITT) criteria ans Supporting advice https:/www.gov.uk/government/publications/initial-teacher-trainingcriteria/initial-teacher-training-itt-criteria-and-supporting-advice Letöltés ideje: 2018. 02. 15.

Gov.UK (2018/a): Guidance Initial teacher training (ITT): accreditation 
https://www.gov.uk/guidance/initial-teacher-training-itt-accreditation Letöltés ideje: 2018. 02. 15.

Gov.UK (2018/b): Statutory guidance Initial teacher training (ITT): criteria and $\begin{array}{lllll}\text { supporting advice } & \text { Updated } & 28 & \text { February }\end{array}$ https://www.gov.uk/government/publications/initial-teacher-trainingcriteria/initial-teacher-training-itt-criteria-and-supporting-advice Letöltés ideje: 2018. 02. 15.

Gov.UK (2018/c): Types of School https://www.gov.uk/types-of-school Letöltés ideje: 2018. 02. 15.

Gov.UK (2018/d): Guidance Funding: initial teacher training (ITT), academic year 2018 to 19 https:/www.gov.uk/guidance/funding-initial-teacher-training-ittacademic-year-2018-to-19 Letöltés ideje: 2018. 02. 15.

Gov.UK (2018/e): Repaying your student loan https://www.gov.uk/repaying-your-studentloan Letöltés ideje: 2018. 02. 15.

Graduate Prospects Ltd. (GB) (2018): How to Become a Teacher https://www.prospects.ac.uk/jobs-and-work-experience/job-sectors/teachertraining-and-education/how-to-become-a-teacher Letöltés ideje: 2018. 02.15.

Halász Gábor (2010): A pedagógusképzés hazai reformja: válogatás a Nemzeti Bologna Bizottság Pedagógusképzési Albizottságának dokumentumaiból. Pedagógusképzés, 2-3. sz. 133-144.

Hobson, Andrew. J. (2013): Személyes közlés

Király Zsolt (2013/a): Tanártovábbképzés Angliában. In: Falus Iván (szerk.): Pedagógustovábbképzés - Nemzetközi áttekintés. Líceum Kiadó, Eger. 79-138.

Király Zsolt (2013/b): Tanfelügyelet, szakfelügyelet és a tanári teljesítmény értékelése Angliában. Pedagógusképzés, 2012-2013 összevont szám, 25-45.

Király Zsolt (2013/c): A pedagógus gyakornoki időszak Angliában. A TÁMOP-3.1.5/122012-0001 Pedagógusképzés támogatása „A "Gyakornoki Minősítő Vizsgák" és a "Pedagógus jelöltek felkészítése" pilot projektek és a minősítési rendszer kidolgozása, és a kidolgozott szempontrendszer alapján vizsgatematikák, eljárásrend, értékelési szempontok kidolgozása és gyakorlati tesztelése" tárgyú kutatás-fejlesztésiinnovációs tevékenység keretében, 2013. https://drive.google.com/folderview?id=0BsJTDhePTiYQkRsclZpLTRQWjg\&usp=sharing Letöltés ideje: 2018. 02. 15.

Király Zsolt (2014): Pedagógus elömeneteli rendszer Angliában. A TÁMOP-3.1.5/12-20120001 Pedagógusképzés támogatása A pedagógusminősítési rendszer kiegészítése, kipróbálása és korrigálása a TÁMOP-3.1.5/12-2012-0001 azonosító számú projekt keretében, $2014 . \quad$ https://drive.google.com/folderview?id=0BsJTDhePTiYQkRsclZpLTRQWjg\&usp=sharing Letöltés ideje: 2018. 02.15.

Legislation.gov.uk (2012): The Education (Induction Arrangements for School Teachers) (England) Regulations 2012 http://www.legislation.gov.uk/uksi/2012/1115/contents/made Letöltés ideje: 2018. 02. 15.

Malderez, Angi (2013): Személyes közlés

MTA Közgazdaság-és Regionális Tudományi Kutatóközpont Közgazdaság-tudományi Intézet (2018): A közoktatás indikátorrendszere 2017 http://www.mtakti.hu/wpcontent/uploads/2018/02/A_kozoktatas_indikatorrendszere_2017.pdf Letöltés 
ideje: 2018. 02. 15.

National Audit Office \& Department for Education (2016): Training new teachers Report by the Comptroller and Auditor General https://www.nao.org.uk/wpcontent/uploads/2016/02/Training-new-teachers-Summary.pdf Letöltés ideje: 2018. 02.15.

OECD (2017): Education at a Glance OECD Indicators 2017 https://www.keepeek.com//Digital-Asset-

Management/oecd/education/education-at-a-glance-2017_eag-2017-en\#page362 Letöltés ideje: 2018. 02. 15.

Ofsted (2018): Initial teacher education inspection handbook https://www.gov.uk/government/uploads/system/uploads/attachment_data/file/6 83714/Initial_teacher_education_inspection_handbook_Ofsted_April_18.pdf Letöltés ideje: 2018. 02. 15.

Quora (2018): What does a2-2 degree mean? https://www.quora.com/What-does-a-2-2degree-mean Letöltés ideje: 2018. 02. 15.

Robinson, W. (2006): Teacher Training in England and Wales: Past, Present and Future Perspectives Education Research and Perspectives Vol. 33, No. 2, 2006 http://erpjournal.net/wp-content/uploads/2012/07/ERPV33-2_Robinsn-W.2006.-Teacher-training-in-England-and-Wales.pdf Letöltés ideje: 2018. 02. 15.

The Conversationist (2016): It's time to rethink teacher training December 7, 2016 https://theconversation.com/its-time-to-rethink-teacher-training-68601 Letöltés ideje: 2018. 02. 15.

The Guardian (2016): Almost a third of teachers quit state sector within five years of qualifying https://www.theguardian.com/education/2016/oct/24/almost-third-ofteachers-quit-within-five-years-of-qualifying-figures Letöltés ideje: 2018. 02. 15.

The Guardian (2017): Cutting workload isn't enough to stop teachers leaving schools https://www.theguardian.com/teacher-network/2017/nov/16/to-stop-teachersleaving-the-profession-lets-help-them-make-a-difference Letöltés ideje: 2018. 02. 15.

The Guardian (2017/a): More than 600,000 pupils in England taught by unqualified teachers, says Labour https://www.theguardian.com/education/2017/jul/25/more-than-600000-pupilsin-england-taught-by-unqualified-teachers Letöltés ideje: 2018. 02. 15.

The Higher Education Academy (2012): Working with the Teachers' Standards in Initial Teacher Education. Guidance to support assessment for Qualified Teacher Status (QTS) https://www.heacademy.ac.uk/system/files/working_with_the_teachers_standar ds_in_ite.pdf Letöltés ideje: 2018. 02.15.

UCAS (2018/a): Teacher Training Entrance Requirements in England https://www.ucas.com/teacher-training-entry-requirements-england Letöltés ideje: 2018. 02. 15.

UCAS (2018/b): Teacher training fees and funding in England https://www.ucas.com/ucas/teacher-training/finance-and-support-traineeteachers Letöltés ideje: 2018. 02. 15.

UCAS (2018/c): Undergraduate tuition fees and student loans 
https://www.ucas.com/ucas/undergraduate/finance-and-support/undergraduatetuition-fees-and-student-loans Letöltés ideje: 2018. 02. 15.

Universities UK (2014): The funding environment for universities 2014 The impact of initial teacher training reforms on English higher education institutions higher. Education in focus http://www.universitiesuk.ac.uk/policy-andanalysis/reports/Documents/2014/impact-of-itt-reforms-on-english-heis.pdf Letöltés ideje: 2018. 02. 15.

University of Liverpool (2018): Ask Liverpool https://ask.liv.ac.uk/friendly.php?slug=faq/86385 Letöltés ideje: 2018. 02.15.

University of Oxford (2018): Careers Service Teaching in Schools https://www.careers.ox.ac.uk/teaching-in-schools/) Letöltés ideje: 2018. 02. 15.

Weston, D. (2012): How effective is the professional development undertaken by teachers? http://www.guardian.co.uk/teacher-network/teacherblog/2012/mar/26/teacher-training-development, 2013 Guardian News and Media Limited Letöltés ideje: 2018. 02. 15. 